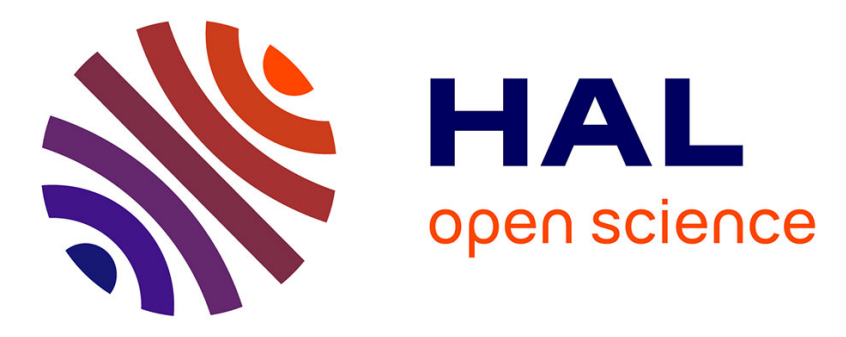

\title{
Effect of flake powder metallurgy on thermal conductivity of graphite flakes reinforced aluminum matrix composites
}

Nabil Chamroune, Diaa Mereib, Florence Delange, Nathalie Caillault, Yongfeng Lu, Jean-Luc Grosseau-Poussard, Jean-François Silvain

\section{To cite this version:}

Nabil Chamroune, Diaa Mereib, Florence Delange, Nathalie Caillault, Yongfeng Lu, et al.. Effect of flake powder metallurgy on thermal conductivity of graphite flakes reinforced aluminum matrix composites. Journal of Materials Science, 2018, 53 (11), pp.8180-8192. 10.1007/s10853-018-2139-1. hal-01779685

\section{HAL Id: hal-01779685 \\ https://hal.science/hal-01779685}

Submitted on 9 May 2018

HAL is a multi-disciplinary open access archive for the deposit and dissemination of scientific research documents, whether they are published or not. The documents may come from teaching and research institutions in France or abroad, or from public or private research centers.
L'archive ouverte pluridisciplinaire HAL, est destinée au dépôt et à la diffusion de documents scientifiques de niveau recherche, publiés ou non, émanant des établissements d'enseignement et de recherche français ou étrangers, des laboratoires publics ou privés. 


\title{
Effect of flake powder metallurgy on thermal conductivity of graphite flakes reinforced aluminum matrix composites
}

\author{
Nabil Chamroune $^{1, \star}$, Diaa Mereib ${ }^{1}$, Florence Delange ${ }^{2}$, Nathalie Caillault $^{2}$, Yongfeng Lu $^{3}$, Jean-Luc \\ Grosseau-Poussard ${ }^{4}$ and Jean-François Silvain ${ }^{1,3}$ \\ ${ }^{1}$ UMR 5026, Institut de Chimie de la Matière Condensée de Bordeaux (ICMCB), 87 Avenue du Docteur Albert Schweitzer, 33600 Pessac, France \\ ${ }^{2}$ Schneider Electric SAS, 38 EQI, Rue Henry Tarze, 38000 Grenoble, France \\ ${ }^{3}$ Department of Electrical and Computer Engineering, University of Nebraska-Lincoln, Lincoln, NE 68588-0511, USA \\ ${ }^{4}$ LaSIE UMR-CNRS 7356, Pole Science et Technologie, Université de La Rochelle, Av. M. Crépeau, 17042 La Rochelle Cedex, France
}

\begin{abstract}
The optimization of metal-matrix composite material is linked firstly with the intrinsic properties of the matrix and the reinforcement used and secondly with the reinforcement-matrix interfacial zone and the distribution/orientation of the reinforcement inside the metal-matrix. Flake powder metallurgy was used to fabricate graphite flake reinforced aluminum matrix (Al/GF) composites fab- ricated by vacuum hot pressing. Two types of aluminum powders morphology were used: spherical $\left(\mathrm{Al}_{\mathrm{S}}\right)$ and flake $\left(\mathrm{Al}_{\mathrm{F}}\right)$ powders. A higher thermal conduc- tivity in the in-plane direction of the graphite flakes was obtained for Al/GF composite materials fabricated with aluminum flake powder. In addition to a better orientation of the GF in the flake aluminum matrix, a 3D puckered surface and plane surface are formed at the Al/GF interface in, respectively, $\mathrm{Al}_{\mathrm{S}} / \mathrm{GF}$ and $\mathrm{Al}_{\mathrm{F}} / \mathrm{GF}$ composite materials. Due to the morphology incompatibility between the graphite flakes and the spherical powder, the damaged inner structure of GF contributes to a limited enhancement of thermal conductivity in $\mathrm{Al}_{\mathrm{S}} / \mathrm{GF}$ composite materials.
\end{abstract}


Many carbon-metal composites are currently used in several applications. One of them concerns their use as heat sinks in microelectronics. Concerning these applications, two conditions are required: a high thermal conductivity (TC) and a coefficient of ther- mal expansion (CTE) similar to the used material type of the electronic device [1-4]. Among carbon reinforcements, diamonds exhibit outstanding thermal properties $\left({ }^{*} 2000 \mathrm{~W} \mathrm{~m}^{-1} \mathrm{~K}^{-}\right.$ 1) [5-7].

However, the applications are limited by high price of diamonds particles and their poor machinability. Pitch-based carbon fibers (FC) are in contrast less expensive and have a good machinability but a lower and anisotropic thermal conductivity (530-1100 W m $\mathrm{W} \mathrm{K}^{-1}$ in the longitudinal direction and 5-10 $\mathrm{W} \mathrm{m}^{-1} \mathrm{~K}^{-1}$ in the transverse direction) $[8,9]$. Graphite flakes (GFs) have significant attention for thermal management applications due to their superior thermal properties, low cost and ease of machining. Indeed, it has been reported that GF exhibits a thermal conductivity higher than $1000 \mathrm{~W} \mathrm{~m}^{-1} \mathrm{~K}^{-1}$ in the plane of graphite flake $[10,11]$ where highly oriented pyrolytic graphite (HOPG) has a thermal conductivity of $1600-2000 \mathrm{~W} \mathrm{~m}^{-1} \mathrm{~K}^{-1}[12,13]$. Out of plane, whatever the graphite type, a TC of 5$10 \mathrm{~W} \mathrm{~m}^{-1} \mathrm{~K}^{-1}$ has been reported [11, 13, 14].

Compared to the others matrices (copper or silver), aluminum has a chemical affinity with carbon, a low density and price, and offers a great advantage in terms of the fabrication of mobile electronic devices and in automobile or aeronautic industries [4].

In structural composites, the idea of flake powder metallurgy is based on nacre as a model system. With this laminated structure composed by aragonite tablets (200-900 $\mathrm{nm}$ thick) and separated by protein collagen layers (10$50 \mathrm{~nm}$ thick), nacre shows remarkable mechanical properties $[15,16,17]$. The advantages of nacre structure have inspired several studies on the development of metal-matrix composite with nanolaminated structure [18]. Aluminum flake powders with large flat surfaces were employed to obtain a significant increase in uniformity, adsorption capacity, two-dimensional alignment of carbon nanotubes (CNT) on Al flakes and an increase in mechanical properties $[19,20,21]$. Flake powder metallurgy was also used to develop $\mathrm{Al} / \mathrm{Al}_{2} \mathrm{O}_{3}$ biomimetic nanolaminated composites with native $\mathrm{Al}_{2} \mathrm{O}_{3}$ skin on $\mathrm{Al}$ flake powder and exhibited excellent combination of strength and ductility [22]. Al-graphene composites with bioinspired nanolaminated structure were fabricated with higher strengthening [23].

In functional metal-matrix composite (MMC), extended works have been reported on reactivity between matrix and reinforcement [24, 25], dispersion and orientation of reinforcement [26], fabrication process [4] (sintering, squeeze casting [27, 28], pressure infiltration process [29]), sintering process (solid-state [8, 10] and liquid-phase sintering [30]). Figure 1 shows the in-plane TC (along the plane of graphite flake) of various Al/GF composite materials reported in the literature. However, few attempts in microstructure design have been carried out especially for thermal properties.

Concerning the powder metallurgy route, several studies reported the fabrication of metal-GF composite materials with a significant increase in TC along the GF principal axis [10, 30]. However, the preferential orientation of GF perpendicular to the pressure axis obtained is not total and some of them remain disordered [10, 31, 32]. Moreover, some deformations of the graphite at the metal-GF interface were reported [30,31,33], but no explanation for that phenomenon has, to our knowledge, been given.

This investigation reports the strategy where flake powder metallurgy was used to prepare graphite flakes (GF)-Al composites by vacuum hot pressing. Two types of aluminum powders morphology were used: spherical (Als) and flake $\left(\mathrm{Al}_{\mathrm{F}}\right)$ powders. Considering the morphology of the reinforcement, flake metallic powders were used to achieve a better (1) orientation of graphite flake in the matrix and (2) morphology compatibility with the graphite flakes. Raman spectroscopy was used as a tool to characterize the graphitic structure of the graphite flakes incorporated inside the $\mathrm{Al}$ matrix.

\section{Materials and methods}

Gas-atomized Al spherical powder (Als; ULTD0065, Hermillon powders, France, Fig. 2a) with an average diameter of $10 \mu \mathrm{m}$ was used as the starting metal powder. $\mathrm{Al}$ spherical powder was also used to prepare $\mathrm{Al}$ flake powder $\left(\mathrm{Al}_{\mathrm{F}}\right.$; Fig. 2b) by wet planetary ball mill. Graphite flakes (GF; Yanxin-Graphite Co., Ltd., Fig. 2c), with an average size and thickness of 550 and $30 \mu \mathrm{m}$, respectively, were added to metal powder. The two components were mixed in turbula mixer (Turbula Shaker/Mixer Model T2C, Germany) for $2 \mathrm{~h}$ to obtain a homogeneous Al/GF distribution.

Planetary ball mill was used to prepare Al flake powder. The spherical powders were placed in $150-\mathrm{ml}$ stainless steel mixing jars containing stainless steel milling balls of 5 and $10 \mathrm{~mm}$ diameter giving an initial ball-to-powder weight ratio of 20:1. Isopropyl alcohol (IPA) was also added (without surfactant) and stirring ball-milled at $200 \mathrm{rpm}$ during $30 \mathrm{~min}$. Individually $\mathrm{Al}$ flakes were obtained by micro-rolling (Fig. 3) with an average size and thickness of 25 and $1 \mu \mathrm{m}$, respectively. Figure 4 shows XRD patterns of Al powder before and after ball milling. No specific contamination 
(Fe for example) induced by ball milling has been detected on the ball-milled $\mathrm{Al}_{\mathrm{F}}$ powder. After compacting the $\mathrm{Al} / \mathrm{GF}$ mixture in a steel mold, cylindrical bulk Al/GF composites $\left(\varnothing 10 \times 8 \mathrm{~mm}^{3}\right)$ were fabricated by hot pressing for $30 \mathrm{~min}$ at $600{ }^{\circ} \mathrm{C}$ under a uniaxial compressive stress of $60 \mathrm{MPa}$ and primary vacuum. The volume fraction of GF in the $\mathrm{Al} / \mathrm{GF}$ composite was fixed at 10, 20, 30, 40 and 50\%. The hot pressing temperature was monitored via a K-type thermocouple located $2 \mathrm{~mm}$ from the sample in the steel mold. Considering that the GF, like carbon fibers [8, 26, 30], tends to be aligned perpendicularly to the uniaxial compressive stress, the cylindrical Al/GF composites were machined to $\varnothing 6 \times 3.5 \mathrm{~mm}^{3}$ in order to measure thermal conductivity in the in-plane and transverse direction (Fig. 5).

\section{Characterization}

Considering that the composite materials only contain closed porosity (ranging from 0.2 and $2.5 \%$ ), the relative density of the Al/GF composites was measured using the Archimedes principle. Microstructural characterization of the $\mathrm{Al} / \mathrm{GF}$ composite was carried out via scanning electron microscopy (SEM; Tescan, VEGA ${ }^{\odot}$ ). In order to reveal the microstructure, $\mathrm{Al} / \mathrm{GF}$ composite was prepared using mechanical polishing with waterproof abrasive silicon carbide papers and polishing cloth. The polished samples were placed in etchant aqueous solution of sodium hydroxide.

Powder X-ray diffraction (XRD) patterns were collected on a PANalytical X'pert PRO MPD diffractometer in BraggBrentano $\theta-\theta$ geometry equipped with a secondary monochromator and $X^{\prime}$ Celerator multi-strip detector. Each measurement was taken within an angular range of $2 \theta=8^{\circ}-80^{\circ}$ and lasted for $34 \mathrm{~min}$. The $\mathrm{Cu}-\mathrm{K}_{\mathrm{\alpha}}$ radiation was generated at $45 \mathrm{kV}$ and $40 \mathrm{~mA}(\lambda=0.15418 \mathrm{~nm})$.

Amount of oxygen was also measured for pure sintered aluminum fabricated with two morphology powders. Hot extraction analyses were carried out to determine the elements concentration of the composite materials, using EMGA-621W oxygen/nitrogen/hydrogen analyzer from Horiba. The estimated values were quantified by a thermal conductivity detector (TCD) and a nondispersive infrared sensor (NDIR), after combustion in a chamber furnace.

Heat capacity was measured by differential scanning calorimetry at $70{ }^{\circ} \mathrm{C}$ (DSC 8000 Pyris Diamond PerkinElmer). Considering that two aluminum powders (spherical and flake) were used, two $C_{\mathrm{p}}$ were measured. Graphite flake, spherical and flake $\mathrm{Al}$ powders have a heat capacity of 836, 921 and $916 \mathrm{~J} \mathrm{~kg}^{-1} \mathrm{~K}^{-1}$, respectively.

The thermal conductivity of Al/GF composites $\left(K_{\mathrm{c}}\right)$ was calculated using the following equation $K_{\mathrm{c}}=a \times \rho \times C_{\mathrm{p}}$ where $a$ is the thermal diffusivity of Al/GF composites measured via the laser flash method (NETZSCH LFA 45, MicroFlash) at $70^{\circ} \mathrm{C}$. The thermal diffusivity was measured in the in-plane and transverse direction. $C_{\mathrm{p}}$ and $\rho$ are the heat capacity and the measured density of the Al/GF composites, respectively. $C_{\mathrm{p}}$ was calculated from heat capacity of graphite and pure $\mathrm{Al}$ by rule of mixture.

Graphite was characterized by Raman spectroscopy. The Raman analyses were done with a high-resolution Horiba spectrometer equipped with a CCD detector; its precision is equal to $0.1 \mathrm{~cm}^{-1}$. Measurements were taken in a backscattering micro-configuration. The wavelength of the source is at $\lambda=532 \mathrm{~nm}$, whose maximum power is equal to $10 \mathrm{~mW}$. The laser power is chosen between 5 and $10 \mathrm{~mW}$ in order to avoid local heating of the samples. This power range is sufficient to obtain a good resolution. All our experiments were performed at room temperature (RT) with a $100 \times$ microscope objective. (The analyzed surface area is about $1.6 \mu \mathrm{m}^{2}$.) Positions of the selected bands have been calculated using Lorentz simulation (Fityk 0.9 .8 curve fitting and data analysis program) after background subtraction.

\section{Results and discussion}

\section{Microstructure}

Figure 6 shows the microstructures of aluminum sintered with $\mathrm{Al}_{\mathrm{S}}$ (Fig. 6a) and with $\mathrm{Al}_{\mathrm{F}}$ (Fig. 6b, c). It has to be noticed that for $\mathrm{Al}_{\mathrm{s}}$ particles, morphology of sintered materials is similar on top and side views (Fig. 6a). Behavior is different for $\mathrm{Al}_{\mathrm{F}}$ particles. In point of fact, side view micrograph (Fig. 6b) and top view micrograph (Fig. 6c) show completely different morphologies. For the side view micrograph, lamellar structure can be observed where final size and morphology of the plates are obviously linked with initial morphology of $\mathrm{Al}_{\mathrm{F}}$ powder obtained by ball milling. Top view morphology should be related to the plane view size of the initial $\mathrm{Al}_{\mathrm{F}}$ powders. Due to stacking of $\mathrm{Al}_{\mathrm{F}}$ powder, an anisotropic microstructure is observed with sintered $\mathrm{Al}_{\mathrm{F}}$ powder. For both $\mathrm{Al}$ morphology, no grain growth and grain morphology evolution can be measured after hot pressing process. Figure 7 shows the side view micrographs of $\mathrm{Al}_{\mathrm{S}} / \mathrm{GF}$ (Fig. 7a-c) and $\mathrm{Al}_{\mathrm{F}} / \mathrm{GF}$ (Fig. 7d-f) composites with 10, 30 and $50 \mathrm{vol} \%$ of graphite (in-plane materials). Dark contrasts are associated with graphite flake and gray one to aluminum matrix. For these two sets of materials, fabricated with spherical and flake aluminum, graphite flakes are preferentially oriented in a plane 
perpendicular to the pressure direction. However, for material fabricated with the Als powder, parts of GF show disorientation (GF in red circles). It has to be mentioned that the number of disordered flakes increases when the volume of GF decreases. For composite materials fabricated with $\mathrm{Al}_{\mathrm{F}}$, such behavior cannot be observed. This difference in morphology can be easily understood by considering the morphology of the initial Al powders. Indeed, during the initial mixing step, for the spherical $\mathrm{Al}$, no specific orientation of the graphite flake can be imposed by the spherical geometry of $\mathrm{Al}$ particles. A 3D orientation of the graphite flake is therefore expected. Behavior is different for the $\mathrm{Al}_{\mathrm{F}}$ due to a similar morphology of both graphite and $\mathrm{Al}$ particles. For that system, $\mathrm{Al}_{\mathrm{F}}$ particles tend to lay on top of the graphite flakes, leading to almost perfect 2D orientation of the both $\mathrm{Al}$ and graphite particles. After hot sintering, a perfect orientation of the graphite particles for $\mathrm{Al}_{\mathrm{F}} / \mathrm{GF}$ system in a plane perpendicular to the pressure direction is observed, whereas some graphite particles are still out of that plane for the $\mathrm{Al}_{\mathrm{S}} / \mathrm{GF}$ systems. Figure 8 shows typical side view micrographs of Al-GF interfaces for $\mathrm{Al}_{\mathrm{S}} / \mathrm{GF}$ (Fig. 8a, c, e) and $\mathrm{Al}_{\mathrm{F}} / \mathrm{GF}$ (Fig. 8b, d, f) composites materials. It can be observed in Fig. 8c, d that the morphology of the Al-GF interface is typically linked with the morphology of densified $\mathrm{Al}_{\mathrm{S}}$ and $\mathrm{Al}_{\mathrm{F}}$ particles as shown in Fig. 6. Therefore, typical 3D puckered surface and plane surface are formed at the $\mathrm{Al}-\mathrm{GF}$ interface in, respectively, $\mathrm{Al}_{\mathrm{S}} / \mathrm{GF}$ and $\mathrm{Al}_{\mathrm{F}} / \mathrm{GF}$ composite materials. Moreover, for a volume fraction of GF equal to $50 \mathrm{vol} \%$, GF/GF contact is observed (red circles in Fig. 8e, f) whatever the Al powder used. Even if deformation of the graphite surface for $\mathrm{Al}_{\mathrm{s}} / \mathrm{GF}$ composite materials was previously reported by Kurita [30], Oddone [31] and Chen [33], no explanation of that phenomena has, to our knowledge, been given. One possible explanation can be given if we take into account the mechanical properties of both Al powders and graphite flakes. Even if Al can be considered as a ductile material (strain close to $25 \%$ ) the deformation of the spherical powder (Fig. 6a, c) sintered under $600{ }^{\circ} \mathrm{C}$ and $60 \mathrm{MPa}$ is quasi null. On the contrary, graphite flakes are considered as brittle materials (strain close to $3 \%$ [34]) and therefore cannot be deformed at the considered sintering conditions. If we consider that no porosity can be observed on the convex side of the Al surface, some surface graphitic planes may break in order to fill the convex gap in between two $\mathrm{Al}_{\mathrm{s}}$ grains. Reasonable illustration of that final state therefore is given in Fig. 9. This specific morphology will be used in order to explain further physical properties of the $\mathrm{Al}_{\mathrm{S}} / \mathrm{GF}$ composite materials.

Figure 10 shows the evolution of the relative densities of the $\mathrm{Al}_{\mathrm{S}} / \mathrm{GF}$ and $\mathrm{Al}_{\mathrm{F}} / \mathrm{GF}$ composite materials with volume fraction of GF going from 0 to $50 \mathrm{vol} \%$ with $10 \mathrm{vol} \%$ step increase. Each value is an average of measurements on three different samples, and the error bars refer to the standard deviation of the three density values. Due to the fact that the $\mathrm{Al}$ powders are covered with an alumina layer whose thickness vary with fabrication process, the oxygen content of the two aluminum powder $\left(\mathrm{Al}_{\mathrm{S}}\right.$ and $\mathrm{Al}_{\mathrm{F}}$ ) has been measured. The $\mathrm{Al}_{\mathrm{S}}$ contained $0.338 \mathrm{wt} \% \mathrm{O}$, whereas the $\mathrm{Al}_{\mathrm{F}}$ contained $1.835 \mathrm{wt} \% \mathrm{O}$. The increase in the oxygen content of the $\mathrm{Al}_{\mathrm{F}}$, with respect to the $\mathrm{Al}_{\mathrm{s}}$ powders, should be linked with the micro-rolled process (Fig. 3) and with the increase in specific surface of the $\mathrm{Al}_{\mathrm{F}}$ compared to $\mathrm{Al}_{\mathrm{S}}$ [22]. Indeed, the formation of passivation oxide layer on the enhanced surface of $\mathrm{Al}_{\mathrm{F}}$ powder explains the excess of oxygen content measured. Additionally, it was reported that powder with flake morphology is more sensitive to oxidation at high temperature [35]. With this quantity of oxygen, an estimation of amorphous aluminum oxide (density of 3.05 [36]) was determined to calculate a theoretical density of sintered $\mathrm{Al}_{\mathrm{S}}(2.703)$ and $\mathrm{Al}_{\mathrm{F}}(2.713)$ materials. These values were used to calculate the relative densities of the Al/GF composite materials. Taking into account these two oxygen contents of the $\mathrm{Al}$ powders, several features are observed in Fig. 10:

1. Whatever the $\mathrm{Al}$ powder used, relative density is higher than $97 \%$. Relative density decreases when the volume fraction of graphite flakes increases. In addition to the porosity which is inherent to the powder metallurgy route, the decrease in the relative density may be correlated with the Al-GF interfacial voids [30] and graphite-graphite contact (Fig. 8e, f) points for high GF content. Indeed, sintering process does not take place at GF/GF contact, which generates porosity [10].

2. The relative density of the $\mathrm{Al}_{\mathrm{F}} / \mathrm{GF}$ materials is always higher than the $\mathrm{Al}_{S} / \mathrm{GF}$ one. This behavior has to be linked with the fact that the stacking of $\mathrm{Al}_{\mathrm{F}}$ and graphite may generate less voids than the stacking of spherical with graphite flakes. Moreover, at high percent of reinforcement, higher specific surface of $\mathrm{Al}_{\mathrm{F}}$ powder allows to minimize contact GF/GF and increase the relative density of $\mathrm{Al}_{\mathrm{F}} / \mathrm{GF}$ composites.

\section{Raman spectroscopy of interfacial graphite flakes in Al/GF system}

Graphite flakes were characterized using Raman spectroscopy close to the Al-GF interfacial zone for both $\mathrm{Al}_{\mathrm{S}} / \mathrm{GF}$ and $\mathrm{Al}_{\mathrm{F}} / \mathrm{GF}$ composite materials. Characteristic vibrational modes of graphite are shown in Fig. 11. The bands at $\sim 1580$ and $\sim 2700 \mathrm{~cm}^{-1}$ are the $G$ and 2D bands, characteristic of graphite materials [37]. The G band is due to the doubly degenerated zone center $\mathrm{E}_{2 \mathrm{~g}}$ mode, and the $2 \mathrm{D}$ band is a second order of zone boundary phonons [38]. At 1350 and $1620 \mathrm{~cm}^{-1}$, bands named D and D' mode, respectively, correspond to disorder induced modes [38], and a weak band at $2450 \mathrm{~cm}^{-1}$ has been reported in graphitic materials [39]. 
Figure 12 shows the optical micrographs of $\mathrm{Al}_{\mathrm{S}} / \mathrm{GF}$ and $\mathrm{Al}_{\mathrm{F}} / \mathrm{GF}$ composite and the different zones where the spectra were acquired (red arrow). As it is visible in Fig. 8c, spherical powder generates deformation of the GF at the interface and in opposition, linear interface was observed with flake powder due to morphology compatibility. Therefore, on $\mathrm{Al}_{\mathrm{S}} / \mathrm{GF}$, Raman acquisition was made on GF between two spherical powder grains in the convex zone (zone 1; Fig. 12a), in the middle of GF (zone 2; Fig. 12a) and in the concave zone (zone 3; Fig. 12a). For the $\mathrm{Al}_{\mathrm{F}} / \mathrm{GF}$ composite material, Raman acquisition was performed on GF next to flake powder (zone A; Fig. 12b) and in the middle of GF (zone B; Fig. 12b). The ratio of the Raman intensity of D peak and G peak $\left(I_{\mathrm{D}} / I_{\mathrm{G}}\right)$ was calculated for each zone in order to characterize the defect quantity in graphitic materials.

Table 1 presents the $I_{\mathrm{D}} / I_{\mathrm{G}}$ ratio (average of at least three acquisitions). For $\mathrm{Al}_{\mathrm{S}} / \mathrm{GF}$ and $\mathrm{Al}_{\mathrm{F}} / \mathrm{GF}$ materials, in the middle of GF (zone 2 and $\mathrm{B}$ ), an equal $I_{\mathrm{D}} / I_{\mathrm{G}}$ ratio is calculated $(0.97$ and 0.98$)$. However, in the interfacial areas, a higher $I_{\mathrm{D}} / I_{\mathrm{G}}$ ratio is calculated in $\mathrm{Al} / \mathrm{S} / \mathrm{GF}$ (zone $1: I_{\mathrm{D}} / I_{\mathrm{G}}=1.2$; zone $3: I_{\mathrm{D}} / I_{\mathrm{G}}=1.06$ ) than $\mathrm{Al}_{\mathrm{F}} / \mathrm{GF}$ composites (zone A: $\left.I_{\mathrm{D}} / I_{\mathrm{G}}=0.94\right)$. Showing that, the quantity of graphitic defect is more important in graphitic interfacial zone for the $\mathrm{Al}_{\mathrm{S}}$ /GF composite materials. As it is shown in Fig. 8, spherical powder induces deformation of graphite flake at the interface as a consequence of the fracture of rigid and brittle graphitic planes on GF (Fig. 9). This fracture increases the quantity of defects and explains the increase in the intensity ratio $I_{\mathrm{D}} / I_{\mathrm{G}}$. Additionally, the puckered nonlinear $\mathrm{Al} \mathrm{s}_{\mathrm{s}} \mathrm{GF}$ interface generates a larger amount of interfaces compared to the linear $\mathrm{Al}_{\mathrm{F}}-\mathrm{GF}$ one. The higher quantity of defects induced at the surface of the GF, by $\mathrm{Al}_{\mathrm{S}}$ geometry, will be used in order to explain further physical properties of the $\mathrm{Al}_{\mathrm{S}} / \mathrm{GF}$ and $\mathrm{Al}_{\mathrm{F}} / \mathrm{GF}$ composite materials.

\section{Thermal conductivity of Al/GF composite materials}

Figure 13a, $\mathrm{b}$ shows the evolution of the thermal conductivity of $\mathrm{Al}_{\mathrm{S}} / \mathrm{GF}$ and $\mathrm{Al}_{\mathrm{F}} / \mathrm{GF}$ composites with different graphite volume fraction, in the in-plane and transverse direction, respectively. Each value is an average of measurements on three different samples, and the error bars refer to the standard deviation of the three TC values. First of all, Fig. 13 shows a thermal conductivity of 218 and $195 \mathrm{~W} \mathrm{~m}^{-1} \mathrm{~K}^{-1}$ for the sintered $\mathrm{Al}_{\mathrm{S}}$ and $\mathrm{Al}_{\mathrm{F}}$ powders, respectively. (Thermal conductivity of $239 \mathrm{~W} \mathrm{~m}^{-1} \mathrm{~K}^{-1}$ is reported for high purity aluminum at $70{ }^{\circ} \mathrm{C}$ [40].) The difference between sintered and high purity aluminum materials is explained by the residual porosity and the native aluminum oxide present on the surface of each aluminum grain. The difference in TC, measured by laser flash method, of the sintered $\mathrm{Al}_{\mathrm{S}}$ and $\mathrm{Al}_{\mathrm{F}}$ materials, is mainly due to an increase in the aluminum oxide contents, generated by the increase in the surface of the flake powder and therefore an increase in thermal Al-GF interface resistance. For more negligible way, contaminants and lattice defects induced by ball milling can also contribute to the decrease in the thermal conductivity of sintered $\mathrm{Al}_{\mathrm{F}}$.

In the in-plane direction (Fig. 13a), the graphite flakes are oriented parallel to the direction of thermal conduction measurement. The in-plane TC increases linearly from 0 to $40 \mathrm{vol} \%$ of GF (zone I). In this zone, the slope of the linear fit is smaller for the $\mathrm{Al}_{\mathrm{S}} / \mathrm{GF}$ composites than for the $\mathrm{Al}_{\mathrm{F}} / \mathrm{GF}$ one. Indeed, $\mathrm{TC}$ of the $\mathrm{Al}_{\mathrm{F}} / \mathrm{GF}$ materials is higher than that of $\mathrm{Al}_{\mathrm{S}} / \mathrm{GF}$ for a GF content greater than $15 \mathrm{vol} \%$. For a GF vol\% greater than $40 \mathrm{vol} \%$, the TC difference between both composites is close to $50 \mathrm{~W} \mathrm{~m}^{-1} \mathrm{~K}^{-1}$ and corresponds to $12.5 \%$ increase in favor of $\mathrm{Al}_{\mathrm{F}} / \mathrm{GF}$ materials. The slope difference and the lower TC values of the $\mathrm{Al}_{\mathrm{S}} / \mathrm{GF}$, with respect to the $\mathrm{Al}_{\mathrm{F}} / \mathrm{GF}$ materials, are explained by the optimized orientation of GF in the matrix, the linear Al-GF interface and the higher relative density of $\mathrm{Al}_{\mathrm{F}} / \mathrm{GF}$ materials, as shown in section "Microstructure". Above the percolation threshold and so for a GF vol\% higher than $40 \mathrm{vol} \%$ [8] (zone II), a decrease in the slope for both composite materials and a more or less equivalent slope is observed. The slope decrease should be linked, firstly, with an amount of Al-GF interfaces which becomes too important for volume fraction exceeding $40 \mathrm{vol} \%$, and secondly, with the increase in the porosity which can take place at the Al-GF interfaces and GF-GF contact points. Indeed, above $40 \mathrm{vol} \%$ of GF, the thermal interface resistance and the porosity level seem to be the two main parameters which govern the TC of these composite materials.

In the transverse direction (Fig. 13b), the graphite flakes are oriented perpendicularly to the direction of thermal conduction measurement. As explained in section "Introduction", thermal conductivity of 5-10 W m $\mathrm{W} \mathrm{K}^{-1}$ has been reported $[12,13]$ for GF out of plane. Consequently, with graphite content increasing from 0 to $50 \mathrm{vol} \%$, thermal conductivity decreases from 190 and $218 \mathrm{~W} \mathrm{~m}^{-1} \mathrm{~K}^{-1}$ for $\mathrm{Al}_{\mathrm{F}}$ and $\mathrm{Al}$, respectively, to $45 \mathrm{~W} \mathrm{~m}^{-1} \mathrm{~K}^{-1}$ (Fig. 13b). The difference in thermal conductivity values between $\mathrm{Al}_{\mathrm{S}} / \mathrm{GF}$ and $\mathrm{Al}_{\mathrm{F}} / \mathrm{GF}$ composite materials decreases when volume fraction of GF increases, and both values are nearly equal for $50 \mathrm{vol} \%$ of GF. Even if the orientation of GF is improved for $\mathrm{Al}_{\mathrm{F}}$ powder, which should result in lower transverse $\mathrm{TC}$ than $\mathrm{Al} / \mathrm{G} / \mathrm{GF}$ materials, the superior relative density and the linear Al-C interface of the obtained $\mathrm{Al}_{\mathrm{F}} / \mathrm{GF}$ materials cause the increase in the transverse TC. All of these factors explain the similar values of transverse $\mathrm{TC}$ of $\mathrm{Al}_{\mathrm{S}} / \mathrm{GF}$ and $\mathrm{Al}_{\mathrm{F}} / \mathrm{GF}$ composite materials. Moreover, unlike in transverse direction, the curve has the behavior of an inverse function: a drastic decrease in thermal conductivity from 0 to $10 \mathrm{vol} \%$ of GF (zone I: $43 \%$ of decrease) and a slower decrease in thermal conductivity from 10 to 50 vol\% of GF 
(zone II: $62 \%$ of decrease). No real explanation can be given for the TC behavior in zone I. In zone II, the evolution of the TC values is coherent with the volume percent of the graphite flakes.

The theoretical calculation of the TC can be performed using different models. The EMA model [41] was chosen to predict the TC of the Al/GF system [42] and then compared with the obtained experimental values. Orientation, geometry, intrinsic TC of the GF and the Al matrix are the factors that were considered to calculate the theoretical TC of the composites materials. General EMA formulations of in-plane TC $\left(K_{c / /}\right)$ and transverse TC $\left(K_{\mathrm{c} \perp}\right)$ are expressed as follows:

$$
\begin{gathered}
K_{\mathrm{c} / /}=K_{\mathrm{m}} \frac{2+f\left[\beta_{\mathrm{L}}\left(1-S_{\mathrm{L}}\right)\left(1+\cos ^{2} \theta\right)+\beta_{\mathrm{T}}\left(1-S_{\mathrm{T}}\right)\left(1-\cos ^{2} \theta\right)\right]}{2-f\left[\beta_{\mathrm{L}} S_{\mathrm{L}}\left(1+\cos ^{2} \theta\right)+\beta_{\mathrm{T}} S_{\mathrm{T}}\left(1-\cos ^{2} \theta\right)\right]} \\
K_{\mathrm{c} \perp}=K_{\mathrm{m}} \frac{1+f\left[\beta_{\mathrm{L}}\left(1-S_{\mathrm{L}}\right)\left(1-\cos ^{2} \theta\right)+\beta_{\mathrm{T}}\left(1-S_{\mathrm{T}}\right) \cos ^{2} \theta\right]}{1-f\left[\beta_{\mathrm{L}} S_{\mathrm{L}}\left(1-\cos ^{2} \theta\right)+\beta_{\mathrm{T}} S_{\mathrm{T}} \cos ^{2} \theta\right]}
\end{gathered}
$$

\section{With}

$$
\begin{aligned}
& \left\langle\cos ^{2} \theta\right\rangle=\frac{\int \rho(\theta) \cos ^{2} \theta \sin \theta \mathrm{d} \theta}{\int \rho(\theta) \sin \theta \mathrm{d} \theta} \\
& \beta_{i}=\frac{K_{i}-K_{\mathrm{m}}}{K_{\mathrm{m}}+S_{i}\left(K_{i}-K_{\mathrm{m}}\right)}, \quad(i=\mathrm{L}, \mathrm{T})
\end{aligned}
$$

The subscripts $\mathrm{L}$ and $\mathrm{T}$ refer to the longitudinal and transverse directions of the GF, respectively. $S$ is the geometrical factor of the reinforcement expressed as $S L=\pi t 4 D$ and $S T=1-\pi t 2 D$, where $D$ and $t$ represent the diameter and thickness of the reinforcement, respectively. $K_{i}$ and $K_{\mathrm{m}}$ are the intrinsic TCs of the GF and the matrix, respectively. $\cos ^{2} \theta$ describes the statistical orientation of the GF, where $\theta$ is the angle between the basal plane of the composite and that of the GF. $\rho(\theta)$ describes the statistical distribution. In this study, Fig. 7 shows that the GF are well oriented in the AlF matrix, then $\langle\cos 2 \theta\rangle \rightarrow 1$

In order to take into account the interfacial thermal resistance, a nonideal interface was introduced by modifying the intrinsic TC of the reinforcement. Therefore, the intrinsic TC of the reinforcement $\left(K_{i}\right)$ has been replaced by an effective TC $\left(K_{i}{ }^{\text {eff }}\right)$ [43]. Equations (1) and (2) are simplified as follows:

$$
\begin{aligned}
& K_{\mathrm{c} / /}=K_{\mathrm{m}}+\frac{f K_{\mathrm{m}}}{S_{\mathrm{L}}(1-f)+\frac{K_{\mathrm{m}}}{K_{\mathrm{L}}^{\text {eff }}-K_{\mathrm{m}}}} \\
& K_{\mathrm{c} \perp}=K_{\mathrm{m}}+\frac{f K_{\mathrm{m}}}{S_{\mathrm{T}}(1-f)+\frac{K_{\mathrm{m}}}{K_{\mathrm{T}}^{\text {eff }}-K_{\mathrm{m}}}}
\end{aligned}
$$

\section{And $K^{\text {eff }}$ is given by}

$$
\begin{aligned}
K_{\mathrm{L}}^{\text {eff }} & =\frac{K_{\mathrm{L}}}{\frac{2 K_{\mathrm{L}}}{h D}+1} \\
K_{\mathrm{T}}^{\text {eff }} & =\frac{K_{\mathrm{T}}}{\frac{2 K_{\mathrm{T}}}{h t}+1}
\end{aligned}
$$


The interfacial thermal conductance $\mathrm{h}$ can be calculated using the acoustic mismatch model (AMM), which treats the interface heat transfer in terms of continuum mechanics by calculating the probability of an incident phonon to pass the interface [43]. $h_{\mathrm{AMM}}$ is given by:

$$
h_{\mathrm{AMM}} \cong \frac{1}{2} \rho_{\mathrm{m}} C_{\mathrm{m}} \frac{v_{\mathrm{m}}^{3}}{v_{r}^{2}} \frac{\rho_{\mathrm{m}} v_{\mathrm{m}} \rho_{\mathrm{r}} v_{\mathrm{r}}}{\left(\rho_{\mathrm{m}} v_{\mathrm{m}}+\rho_{\mathrm{r}} v_{\mathrm{r}}\right)^{2}}
$$

where $\rho, C$ and $v$ are the density, the specific heat capacity and the Debye phonon velocity, respectively. Subscripts $m$ and $\mathrm{r}$ refer to the matrix and the reinforcement, respectively. The material parameters for the calculations are given in Table 2. For an Al/GF system, the interfacial thermal conductance $h_{\mathrm{AMM}}$ calculated with Eq. (9) is equal to $4.62 \times 10^{7} \mathrm{~W} \mathrm{~m}^{-2} \mathrm{~K}^{-1}$, which is in accordance with the value calculated by Zhou [27]. Considering the interfacial thermal resistance, the effective TC of GF was calculated using Eqs. (7) and (8). Values of 927 and $9.86 \mathrm{~W} \mathrm{~m}^{-1} \mathrm{~K}^{-1}$ were calculated for $K_{\mathrm{L}}$ eff and $K_{\mathrm{T}}$ eff , respectively, with $K_{\mathrm{m}}, K_{\mathrm{L}}$ and $K_{\mathrm{T}}$ of 195,1000 and $10 \mathrm{~W} \mathrm{~m}^{-1} \mathrm{~K}^{-1}$ [10, 11], respectively.

Figure 13a shows the theoretical values of $K_{\mathrm{c} / /}$ (red line), calculated using Eq. (5) for typical Al/GF composites materials, and the experimental values for both $\mathrm{Al} / \mathrm{GF}$ composites fabricated using $\mathrm{Al}_{\mathrm{S}}$ and $\mathrm{Al}_{\mathrm{F}}$ powders. For a $\mathrm{GF}$ volume fraction lower than $20 \%$, the theoretical model fits the experimental TC whatever the Al particles used. However, for volume fractions between 20 and 40, experimental values are lower than the theoretical ones. This difference in TC increases when the GF volume fraction increases. After $40 \mathrm{vol} \%$ of GF (zone 2), a significant mismatch between the EMA model and the experimental TC of $\mathrm{Al}_{\mathrm{F}} / \mathrm{GF}$ and $\mathrm{Al}_{\mathrm{S}} / \mathrm{GF}$ composites is observed. It can also be noticed that the experimental TC of $\mathrm{Al}_{\mathrm{F}} / \mathrm{GF}$ composites are much closer to the calculated TC by the EMA model than the $\mathrm{Al}_{\mathrm{s}} / \mathrm{GF}$ ones.

In order to fit the theoretical and experimental TC, the thermal conductance $h$ at the Al-GF interface can be adjusted (dashed red line in Fig. 13a). In zone 1 , for $\mathrm{Al}_{\mathrm{F}} / \mathrm{GF}$ materials, thermal conductance ( $\mathrm{h}_{\mathrm{FIT}}$ ) is equal to $2.8 \times 10^{7} \mathrm{~W} \mathrm{~m}^{-2} \mathrm{~K}^{-1}$, and in zone $2, h_{\mathrm{FIT}}$ is equal to $1.15 \times 10^{7} \mathrm{~W} \mathrm{~m}^{-2} \mathrm{~K}^{-1}$. The difference between the thermal conductance calculated using the AMM ( $h_{\mathrm{AMM}}$ is equal to $\left.4.62 \times 10^{7} \mathrm{~W} \mathrm{~m}^{-2} \mathrm{~K}^{-1}\right)$ and $h_{F I T}$ values can be explained by the fact that AMM is based on the assumption of a perfect Al-GF bonding interface. In fact, there is a mechanical Al$\mathrm{Al}_{2} \mathrm{O}_{3}$-GF interface due to the passivation layer present on the $\mathrm{Al}$ powder and porosity generated by nanovoids at the Al-GF interface [30]. Then, the decrease in $h_{\mathrm{FIT}}$ between zones 1 and 2 has to be correlated with the formation of significant GF-GF interfaces (and porosity) which should be considered as an additional type of interface with its own conductance.

Figure $13 \mathrm{~b}$ shows the theoretical values of $K_{\mathrm{c} \perp}$ for $\mathrm{Al}_{\mathrm{F}} / \mathrm{GF}$ composite materials (red line). In this direction, the EMA prediction is in fairly good agreement with the experimental $\mathrm{TCs}$ of $\mathrm{Al}_{\mathrm{F}} / \mathrm{GF}$ composite materials. Indeed, in the transverse direction, the intrinsic TC of GF is significantly lower $\left(10 \mathrm{~W} \mathrm{~m}^{-1} \mathrm{~K}^{-1}\right)$ than that of the $\mathrm{Al}$ matrix; consequently, the heat transfer is mainly controlled by the $\mathrm{Al}$ matrix. The interfacial thermal conductance has, therefore, much less effect on the TC of the composite materials, resulting in the same theoretical TC of Al/GF composites with either $h_{\mathrm{AMM}}$ or $h_{\mathrm{FIT}}$.

\section{Conclusion}

Graphite flake reinforced aluminum matrix composites were fabricated by powder metallurgy via hot pressing. Two types of aluminum powders were used and mixed with graphite flake reinforcement: spherical and flake powders. A stratified microstructure (anisotropic microstructure) was obtained with a preferential orientation of the flakes perpendicular to the stress axis in contrast to the typical microstructure (isotropic microstructure) of a sintered spherical powder. From $15 \mathrm{vol} \%$ of GF, it has been shown that the thermal conductivity perpendicular to the stress axis was higher for $\mathrm{Al} / \mathrm{GF}$ composite materials made with aluminum flake powder than with spherical powder. The $\mathrm{TC}$ of $\mathrm{Al} / 50 \mathrm{vol} \%$ composite in the in-plane direction, increased from 400 ( $\left.\mathrm{Al}_{\mathrm{S}} / \mathrm{GF}\right)$ to $450 \mathrm{~W} \mathrm{~m}^{-1} \mathrm{~K}^{-1}\left(\mathrm{Al}_{\mathrm{F}} / \mathrm{GF}\right)$. This result is explained by three main reasons:

1. Microstructural analysis has shown that $\mathrm{Al}$ flake powder induces an orientation of GF in a plane perpendicular to the pressure direction. However, for material fabricated with the spherical Al powder, part of GFs shows geometric disorientation with respect to this plane.

2. Deformation at the metal/carbon interface with the spherical powder was observed. Due to the morphology incompatibility between flake graphite and spherical powder, aluminum generates fracture of graphitic plane which may result in the deterioration of thermal conductivity of graphite flake. Graphite 
flakes were characterized by Raman spectroscopy in the interfacial zone of Al/GF composite materials and show a higher quantity of defects in GF contained in $\mathrm{Al}_{S} / \mathrm{GF}$ than $\mathrm{Al}_{\mathrm{F}} / \mathrm{GF}$ interface.

3. Finally, it has been shown that even the relative density of the two types of composite materials (Als/GF and $\mathrm{Al}_{\mathrm{F}} / \mathrm{GF}$ ) decreased when the fraction of reinforcement increased, the relative density of $\mathrm{Al}$ flake-based composite is higher than the spherical based composite whatever the GF volume fraction.

Flake powder metallurgy process can therefore be used in order to prevent the damage of brittle reinforcements, with planar morphology, and provide a specific orientation of the reinforcements with anisotropic properties.

\section{Acknowledgements}

This work was funded by the University of Bordeaux (2015-FD-24).

\section{Compliance with ethical standards}

Conflict of interest The authors declare that they have no conflict of interest.

\section{References}

1. Zweben C (1998) Advances in composite materials for thermal management in electronic packaging. JOM 50(6):47-51.

2. Zweben C (2005) Ultrahigh-thermal-conductivity packaging materials. In: Annual IEEE semiconductor thermal measurement and management symposium, pp 168-174.

3. Rohatgi PK (1993) Metal-matrix composites. Defence Sci J 43(4):323-349.

4. Mallik S, Ekere N, Best C, Bhatti R (2011) Investigation of thermal management materials for automotive electronic control units. Appl Therm Eng 31(2-3):355-362.

5. Yoshida K, Morigami H (2004) Thermal properties of diamond/copper composite material. Microelectron Reliab 44(2):303-308.

6. Ruch PW, Beffort O, Kleiner S, Weber L, Uggowitzer PJ (2006) Selective interfacial bonding in Al(Si)-diamond composites and its effect on thermal conductivity. Compos Sci Technol 66(15):2677-2685.

7. Beffort O, Khalid FA, Weber L, Ruch P, Klotz UE, Meier S, Kleiner S (2006) Interface formation in infiltrated $\mathrm{Al}(\mathrm{Si}) /$ diamond composites. Diam Relat Mater 15(9):1250-1260.

8. Kurita H, Feuillet E, Guillemet T, Heintz J-M, Kawasaki A, Silvain J-F (2014) Simple fabrication and characterization of discontinuous carbon fiber reinforced aluminum matrix composite for lightweight heat sink applications. Acta Metall Sin (English Lett) 27(4):714-722.

9. Pierson HO (1993) Handbook of carbon, graphite, diamond and fullerenes. Noyes Publications, Park Ridge, pp 194-195

10. Chen JK, Huang IS (2013) Thermal properties of aluminum-graphite composites by powder metallurgy. Compos Part B Eng 44(1):698-703.

11. Murakami M, Nishiki N, Nakamura K, Ehara J, Okada H, Kouzaki T, Watanabe K et al (1992) Yoshimura, S. High-quality and highly oriented graphite block from polycondensation polymer films. Carbon 30(2):255-262.

12. Klemens PG, Pedraza DF (1994) Thermal conductivity of graphite in the basal plane. Carbon 32(4):735-741.

13. Fu Q, Yang J, Chen Y, Li D, Xu D (2015) Experimental evidence of very long intrinsic phonon mean free path along the caxis of graphite. Appl Phys Lett 106(3):031905.

14. Huang Y, Su Y, Li S, Ouyang Q, Zhang G, Zhang L, Zhang D (2016) Fabrication of graphite film/aluminum composites by vacuum hot pressing: process optimization and thermal conductivity. Compos B Eng 107:43-50.

15. Tao P, Shang W, Song C, Shen Q, Zhang F, Luo Z, Yi N, Zhang D, Deng T (2015) Bioinspired engineering of thermal materials. Adv Mater 27(3):428-463.

16. Metzler RA, Abrecht M, Olabisi RM, Ariosa D, Johnson CJ, Frazer BH, Coppersmith SN et al (2007) Architecture of columnar nacre, and implications for its formation mechanism. Phys Rev Lett 98(26):268102.

17. Rousseau M, Lopez E, Stempflé P, Brendlé M, Franke L, Guette A, Naslain R et al (2005) Multiscale structure of sheet nacre. Biomaterials 26(31):6254-6262.

18. Fan G, Xu R, Tan Z, Zhang D, Li Z (2014) Development of flake powder metallurgy in fabricating metal-matrix composites: a review. Acta Metall Sin (English Lett) 27(5):806-815.

19. Jiang L, Fan G, Li Z, Kai X, Zhang D, Chen Z, Humphries S et al (2011) An approach to the uniform dispersion of a high volume fraction of carbon nanotubes in aluminum powder. Carbon 49(6):1965-1971.

20. Jiang L, Li Z, Fan G, Cao L, Zhang D (2012) The use of flake powder metallurgy to produce carbon nanotube (CNT)/aluminum composites with a homogenous CNT distribution. Carbon 50(5):1993-1998.

21. Jiang L, Li Z, Fan G, Cao L, Zhang D (2012) Strong and ductile carbon nanotube/aluminum bulk nanolaminated composites with two-dimensional alignment of carbon nanotubes. Scr Mater 66(6):331-334.

22. Jiang L, Li Z, Fan G, Zhang D (2011) A flake powder metallurgy approach to $\mathrm{Al}_{2} \mathrm{O}_{3} / \mathrm{Al}$ biomimetic nanolaminated composites with enhanced ductility. Scr Mater 65(5):412-415.

23. Li Z, Guo Q, Li Z, Fan G, Xiong D-B, Su Y, Zhang J et al (2015) Enhanced mechanical properties of graphene (reduced graphene oxide)/aluminum composites with a bioinspired nanolaminated structure. Nano Lett. 15(12):8077-8083. 
24. Weber L, Tavangar $\mathrm{R}$ (2007) On the influence of active element content on the thermal conductivity and thermal expansion of $\mathrm{Cu}-\mathrm{X}(\mathrm{X}=\mathrm{Cr}, \mathrm{B})$ diamond composites. Scr Mater 57(11):988-991.

25. Azina C, Roger J, Joulain A, Mauchamp V, Mortaigne B, Lu YF, Silvain J-F (2018) Solid-liquid co-existent phase process: towards fully dense and thermally efficient $\mathrm{Cu} / \mathrm{C}$ composite materials. J Alloy Compd 738:292-300.

26. Molina JM, Louis E (2015) Anisotropy in thermal conductivity of graphite flakes-SiCp/matrix composites: implications in heat sinking design for thermal management applications. Mater Charact 109:107-115.

27. Zhou C, Huang W, Chen Z, Ji G, Wang ML, Chen D, Wang HW (2015) In-plane thermal enhancement behaviors of Al matrix composites with oriented graphite flake alignment. Compos B Eng 70:256-262.

28. Li W, Liu Y, Wu G (2015) Preparation of graphite flakes/Al with preferred orientation and high thermal conductivity by squeeze casting. Carbon 95:545-551.

29. Prieto R, Molina JM, Narciso J, Louis E (2011) Thermal conductivity of graphite flakes-SiC particles/metal composites. Compos Part A Appl Sci Manuf 42(12):1970-1977.

30. Kurita H, Miyazaki T, Kawasaki A, Lu Y, Silvain J-F (2015) Interfacial microstructure of graphite flake reinforced aluminum matrix composites fabricated via hot pressing. Compos A Appl Sci Manuf 73:125-131.

31. Oddone V, Boerner B, Reich S (2017) Composites of aluminum alloy and magnesium alloy with graphite showing low thermal expansion and high specific thermal conductivity. Sci Technol Adv Mater 18(1):180-186.

32. Liu Q, He X-B, Ren S-B, Zhang C, Ting-Ting L, Qu X-H (2014) Thermophysical properties and microstructure of graphite flake/copper composites processed by electroless copper coating. J Alloy Compd 587:255-259.

33. Chen J, Ren S, He X, Qu X (2017) Properties and microstructure of nickel-coated graphite flakes/copper composites fabricated by spark plasma sintering. Carbon 121:25-34.

34. Seldin EJ (1966) Stress-strain properties of polycrystalline graphites in tension and compression at room temperature. Carbon 4(2):177-191.

35. Hasani S, Panjepour M, Shamanian M (2012) The oxidation mechanism of pure aluminum powder particles. Oxid Metals 78(3-4):179-195.

36. Levin I, Brandon D (1998) Metastable alumina polymorphs: crystal structures and transition sequences. J Am Ceram Soc 81(8):1995-2012.

37. Vidano RP, Fischbach DB, Willis LJ, Loehr TM (1981) Observation of Raman band shifting with excitation wavelength for carbons and graphites. Solid State Commun 39(2):341-344.

38. Tuinstra F, Koenig JL (1970) Raman spectrum of graphite. J Chem Phys 53(3):1126-1130.

39. Pimenta MA, Dresselhaus G, Dresselhaus MS, Cançado LG, Jorio A, Saito R (2007) Studying disorder in graphite-based systems by Raman spectroscopy. Phys Chem Chem Phys 9(11):1276-1291.

40. Ho CY, Powell RW, Liley PE (1972) Thermal conductivity of the elements. J Phys Chem Ref Data 1(2):279-421.

41. Nan C-W, Birringer R, Clarke DR, Gleiter H (1997) Effective thermal conductivity of particulate composites with interfacial thermal resistance. J Appl Phys 81(10):6692-6699.

42. Ren S, Chen J, He X, Qu X (2018) Effect of matrix-alloying-element chromium on the microstructure and properties of graphite flakes/copper composites fabricated by hot pressing sintering. Carbon 127:412-423.

43. Molina JM, Prieto R, Narciso J, Louis E (2009) The effect of porosity on the thermal conductivity of $\mathrm{Al}-12 \mathrm{wt} \% \mathrm{Si} / \mathrm{SiC}$ composites. Scr Mater 60(7):582-585.

44. Prasher R (2008) Thermal boundary resistance and thermal conductivity of multiwalled carbon nanotubes. Phys Rev B Condens Matter Mater Phys 77(7):075424.

45. Swartz ET, Pohl RO (1989) Thermal boundary resistance. Rev Mod Phys 61(3):605-668.

Table 1 Raman intensity ratio ID/IG of GF in different zones

\begin{tabular}{llll}
\hline $\mathrm{Al}_{\mathrm{S}} / \mathrm{GF}\left(I_{\mathrm{D}} / I_{\mathrm{G}}\right)$ & Zone 1 & Zone 2 & Zone 3 \\
& 1.2 & 0.97 & 1.06 \\
$\mathrm{Al}_{\mathrm{F}} / \mathrm{GF}\left(I_{\mathrm{D}} / I_{\mathrm{G}}\right)$ & Zone A & Zone B & - \\
& 0.94 & 0.98 & - \\
\hline
\end{tabular}

Table 2 Materials parameters for calculating the interfacial thermal conductance for composites

\begin{tabular}{lllll}
\hline Material & Density $\left(\mathrm{kg} \mathrm{m}^{-3}\right)$ & Specific heat $\left(\mathrm{J} \mathrm{kg}^{-1} \mathrm{~K}^{-1}\right)$ & Debye phonon velocity $\left(\mathrm{m} \mathrm{s}^{-1}\right)$ & Refs. \\
\hline Graphite & 2260 & 836 & 14800 & {$[44]$} \\
Flake Al & 2713 & 916 & 3595 & {$[45]$} \\
\hline
\end{tabular}




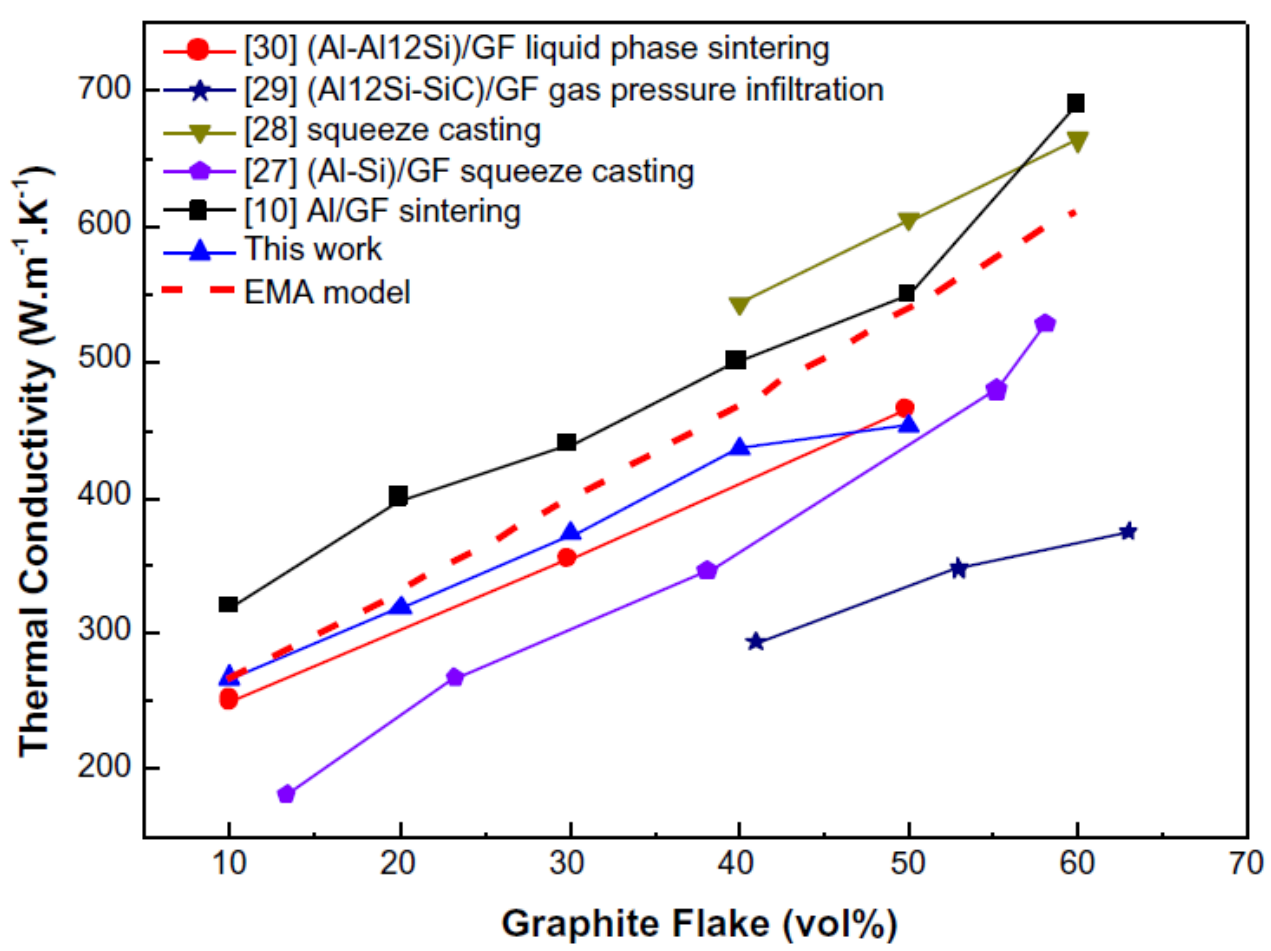

Figure 1 In-plane $\mathrm{TC}$ of several $\mathrm{Al} / \mathrm{GF}$ composite materials previously reported in the literature.
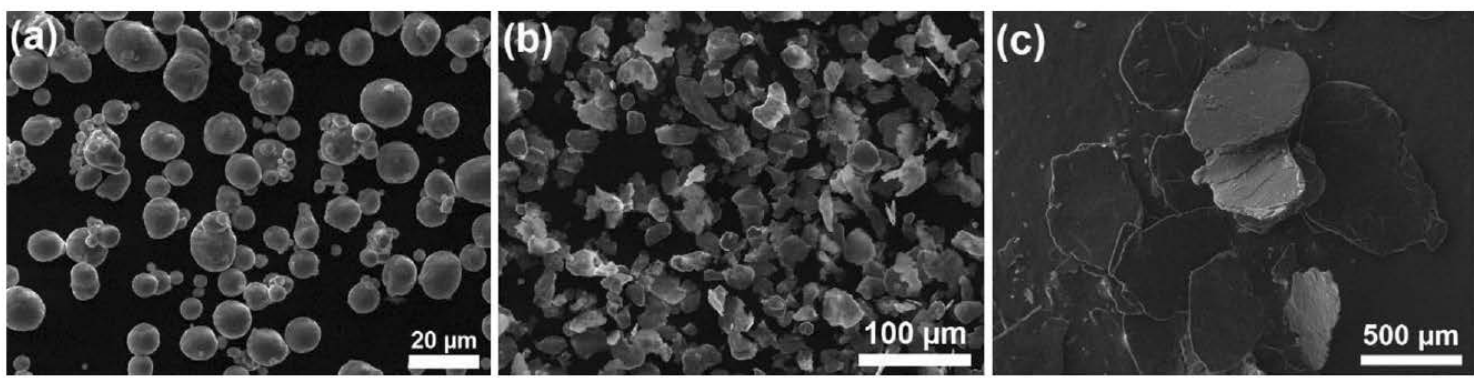

Figure 2 SEM micrographs of starting materials. a Spherical Al powder, $\mathbf{b}$ flake Al powder, and $\mathbf{c}$ graphite flakes.
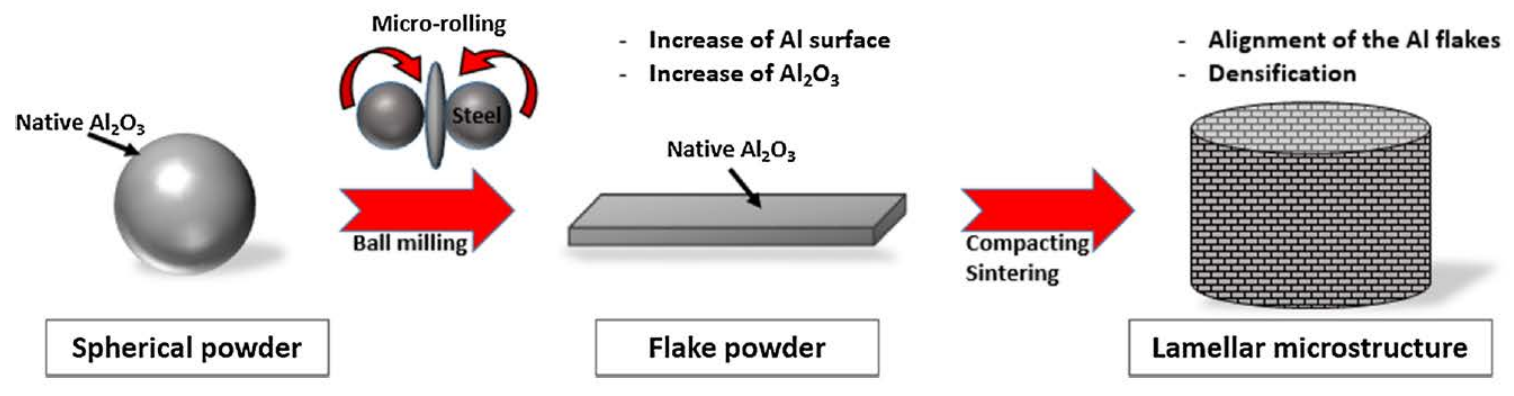

Figure 3 Preparation of lamellar material by flake powder metallurgy. 


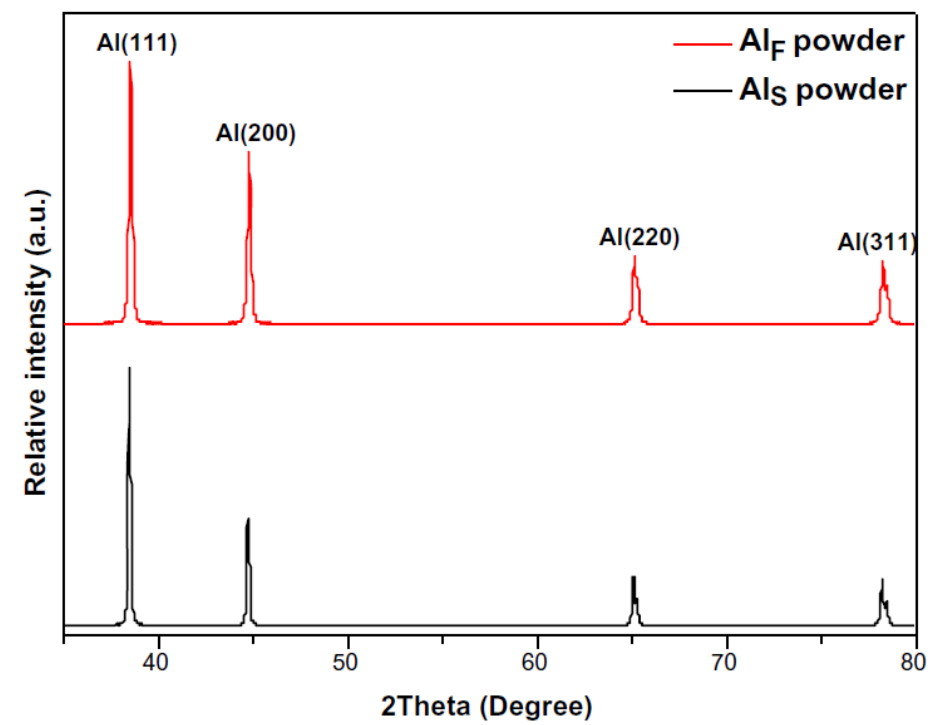

Figure 4 XRD patterns of $\mathrm{Al}_{\mathrm{S}}$ powder (black) and $\mathrm{Al}_{\mathrm{F}}$ powder (red).
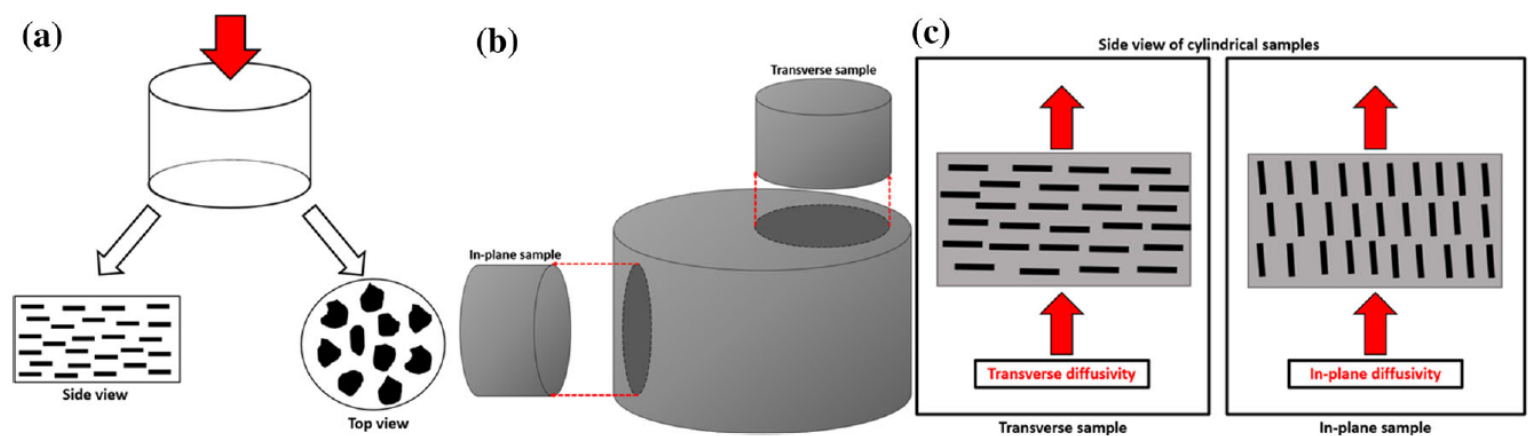

Figure 5 a Orientation of GF perpendicularly to the uniaxial compressive stress. $\mathbf{b}$ Machining process of Al/GF composite materials in order to prepare samples for the measurement of (c) transverse diffusivity ( $\perp$ to the GF) and $\mathbf{c}$ in-plane diffusivity (// to the GF).
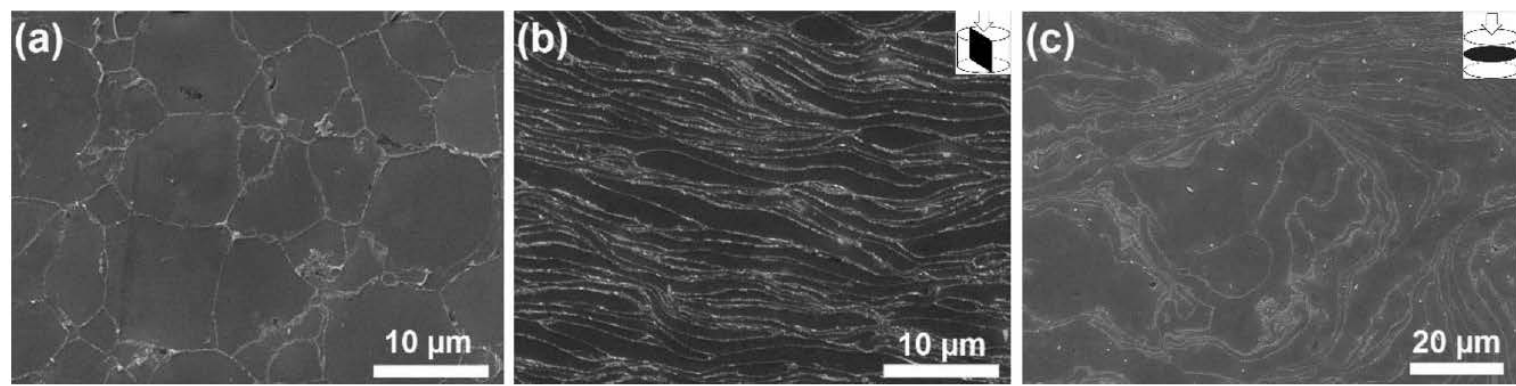

Figure 6 SEM micrographs of sintered Al powder. a Spherical Al powder (side view), (b) flake Al powder and (c) flake Al powder (top view). 

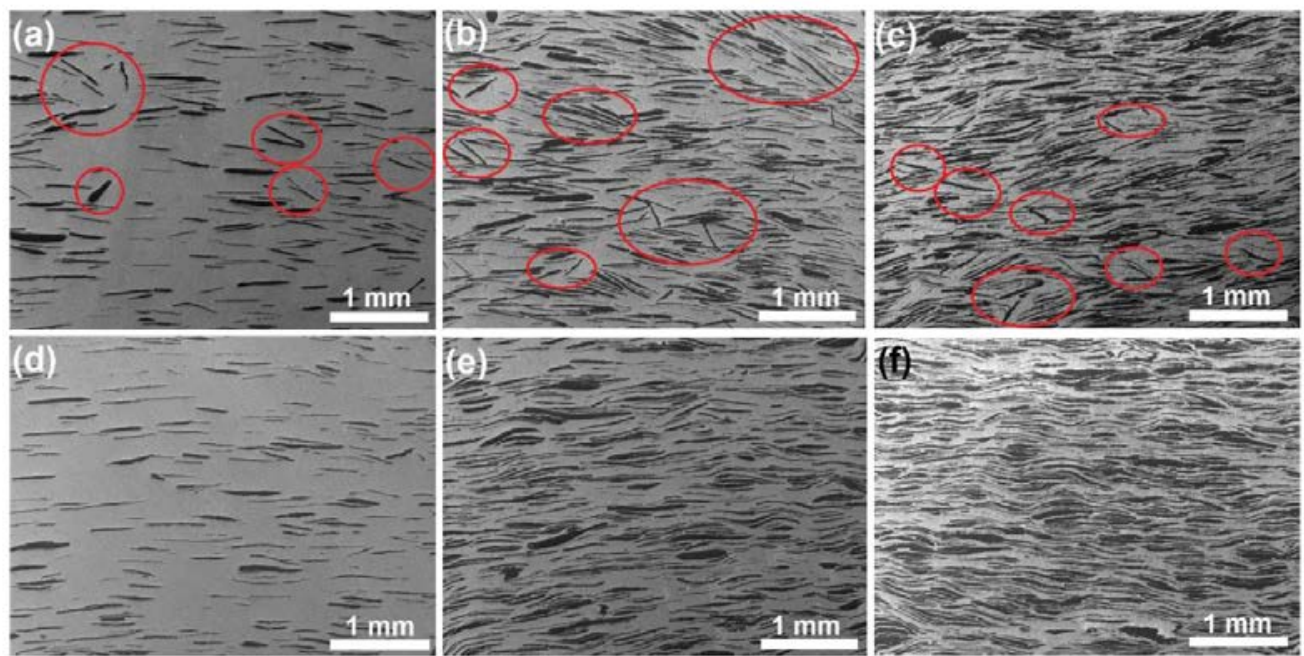

Figure $7 \mathrm{SEM}$ micrographs (side view) of $\mathrm{Al}_{\mathrm{S}} / \mathrm{GF}(\mathrm{a}-\mathrm{c})$ and $\mathrm{Al}_{\mathrm{F}} / \mathrm{GF}(\mathrm{d}-\mathrm{f})$ composite materials with $(\mathrm{a}, \mathrm{d}) 10 ;(\mathrm{b}, \mathrm{e}) 30$; and (c. f) $50 \mathrm{vol} \%$.
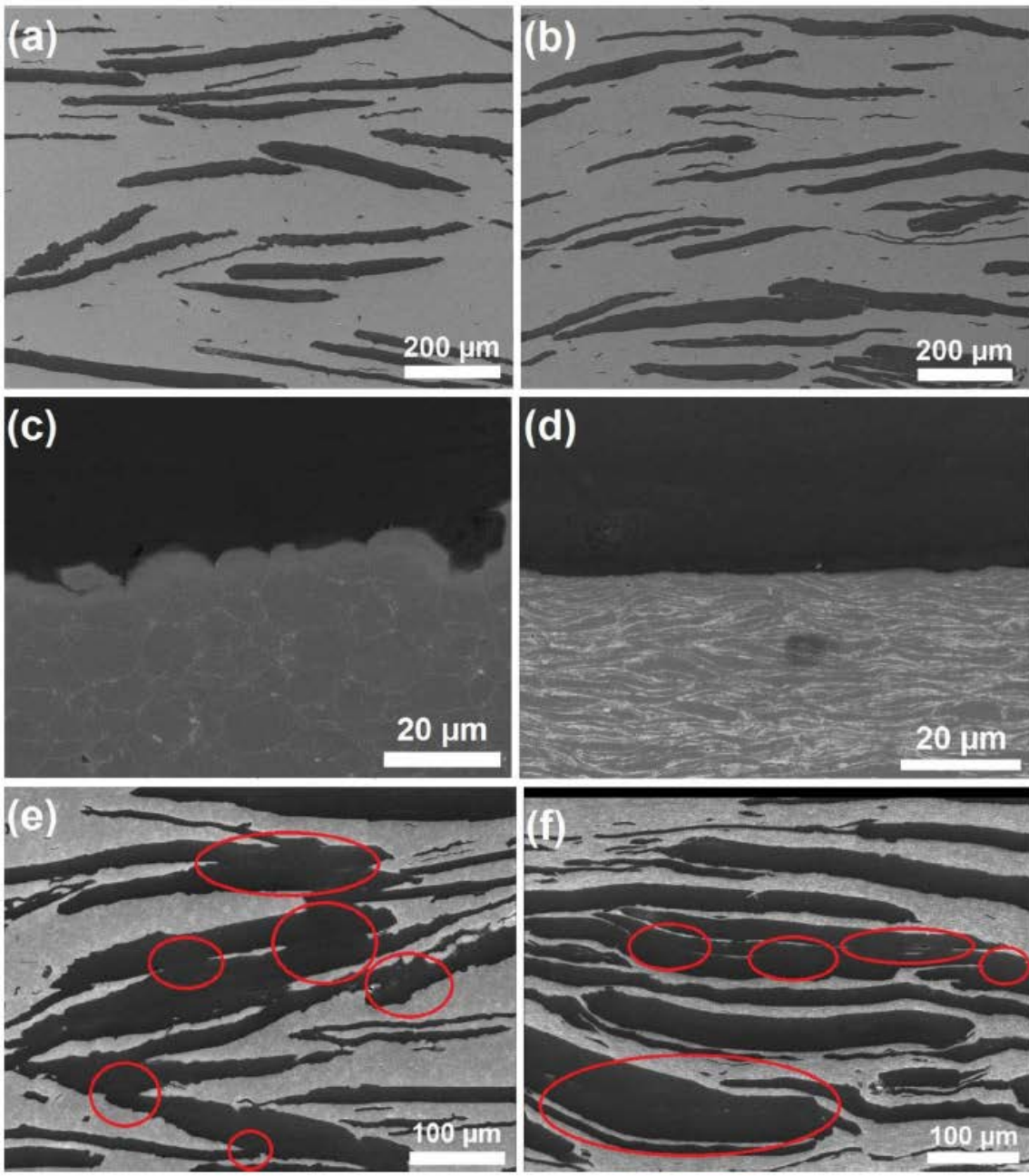

Figure 8 SEM micrographs (side view) of $\mathrm{Al}_{\mathrm{S}} / 30 \mathrm{vol} \% \mathrm{GF}$ (a, c); $\mathrm{Al}_{\mathrm{F}} / 30 \mathrm{vol} \% \mathrm{GF}$ (b, d); $\mathrm{Al}_{\mathrm{S}} / 50 \mathrm{vol} \% \mathrm{GF}$ (e); and $\mathrm{Al}_{\mathrm{F}} / 50$ vol $\% \mathrm{GF}$ (f) composite materials.

Figure 9 Illustration of interfacial zone in $\mathrm{Al}_{\mathrm{S}} / \mathrm{GF}$ composite material.

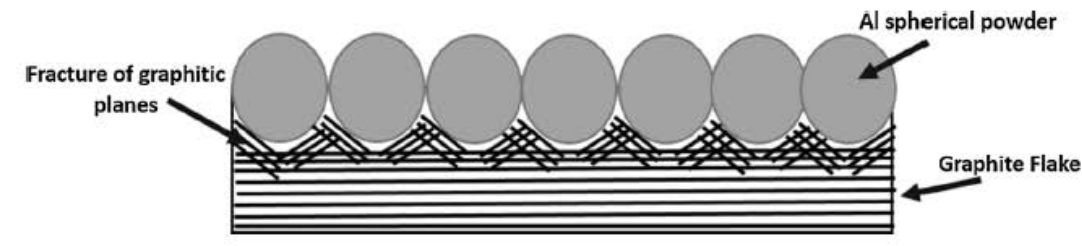




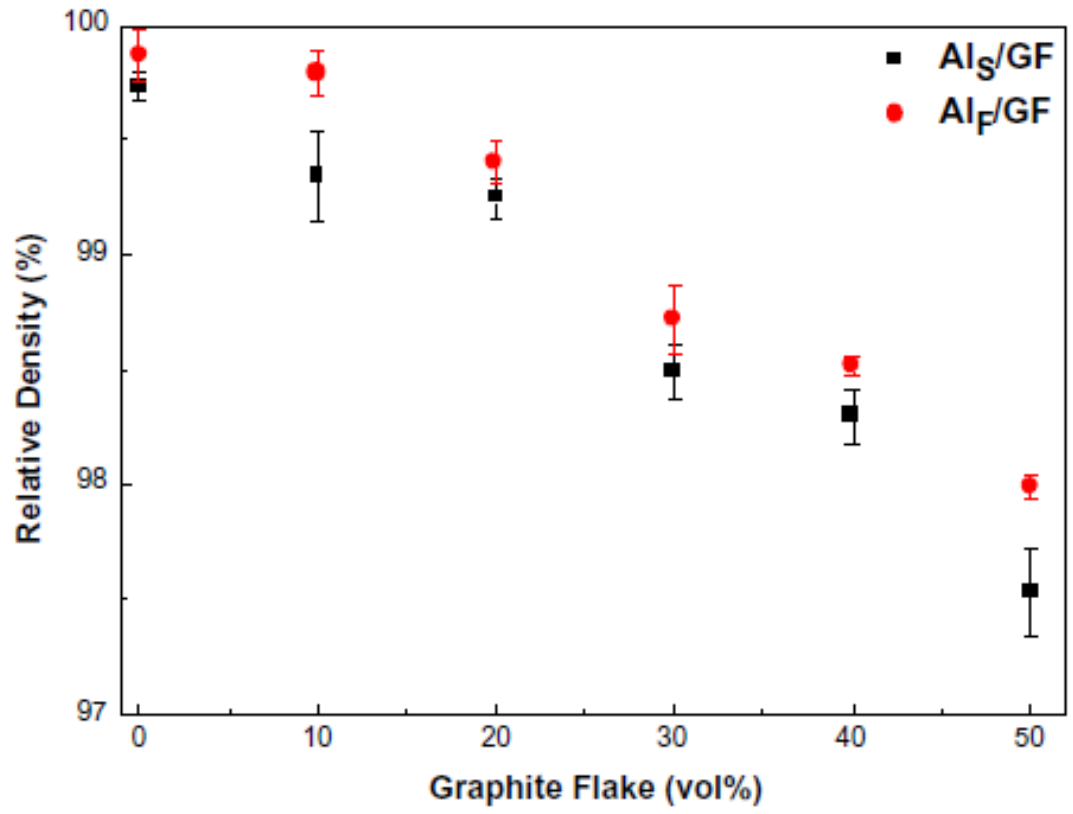

Figure 10 Relative densities of $\mathrm{Al}_{\mathrm{S}} / \mathrm{GF}$ (black squares) and $\mathrm{Al}_{\mathrm{F}} /$ GF (red circles) composite materials as function of vol $\%$ of graphite flakes.

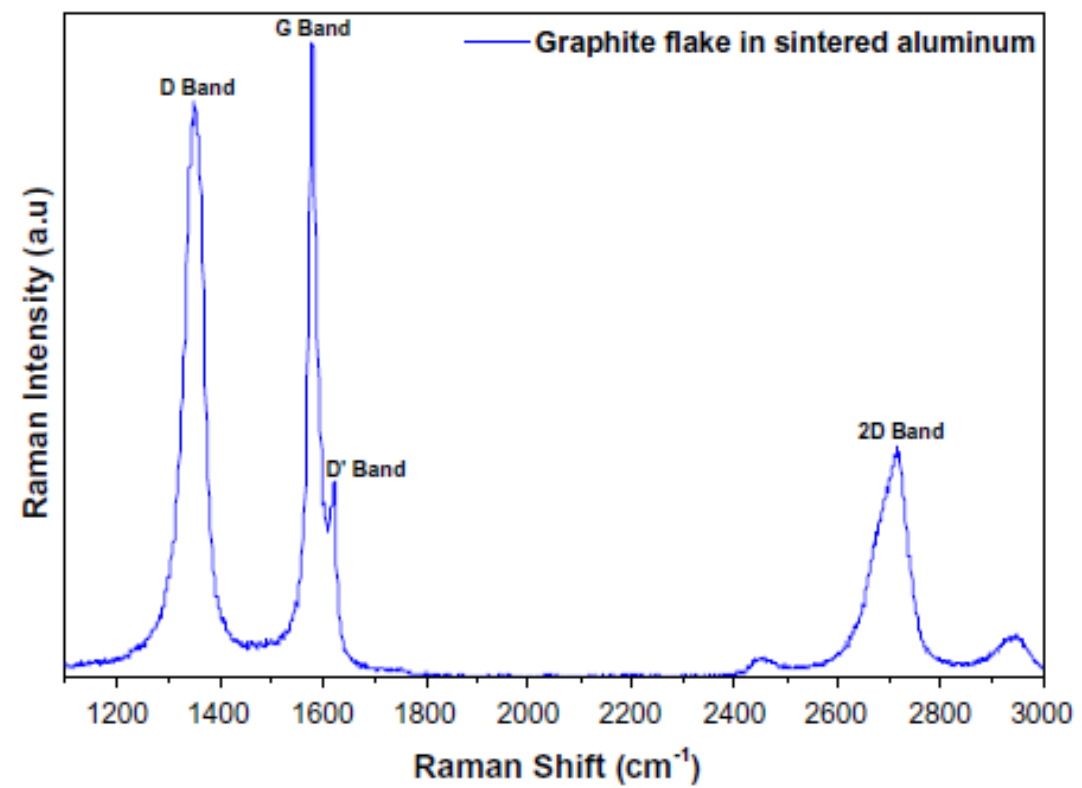

Figure 11 Raman spectra in the range of $1100-3000 \mathrm{~cm}^{-1}$ of graphite flake in sintered aluminum. 

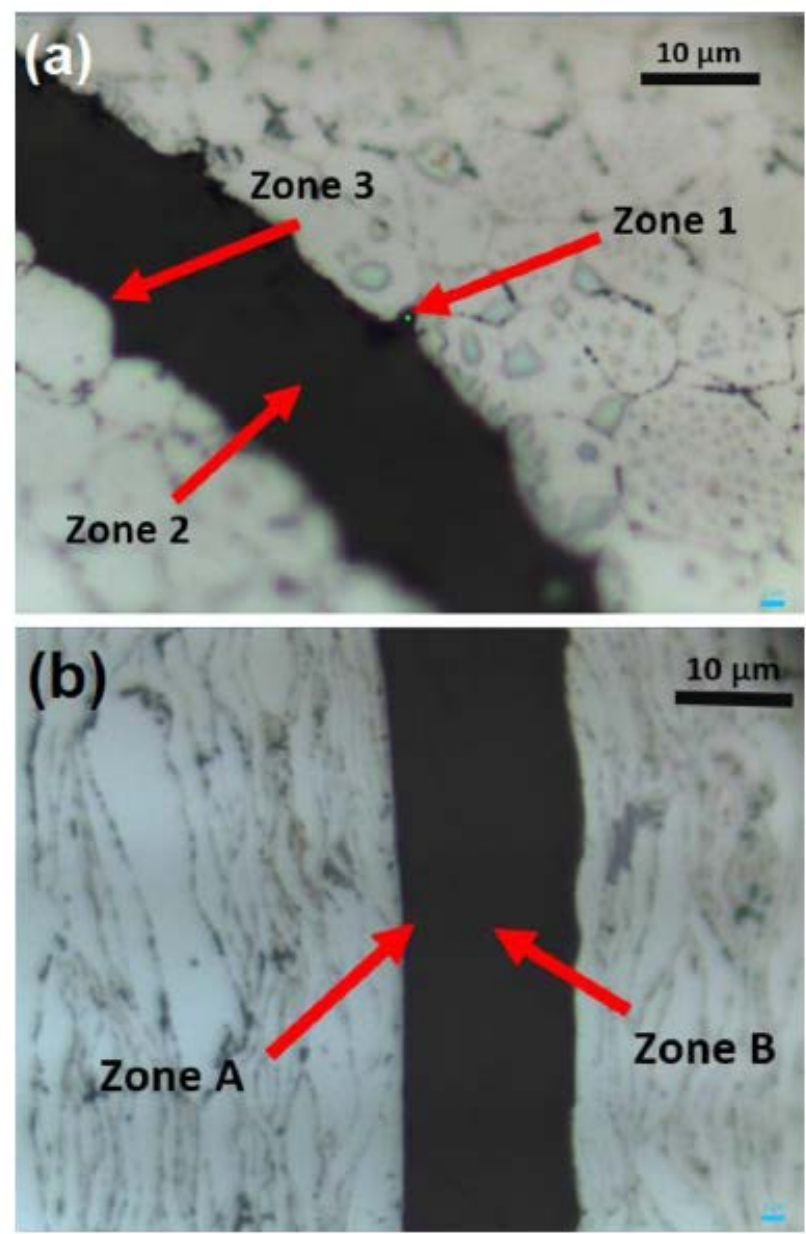

Figure 12 Optical micrographs of $\mathrm{Al}_{\mathrm{S}} / \mathrm{GF}$ (a) and $\mathrm{Al}_{\mathrm{F}} / \mathrm{GF}$ (b) composite materials and the different zones: zone 1, 2, 3 (a) for $\mathrm{Al}_{\mathrm{S}} / \mathrm{GF}$; zone $\mathrm{A}-\mathrm{B}$ (b) for $\mathrm{Al}_{\mathrm{F}} / \mathrm{GF}$. 

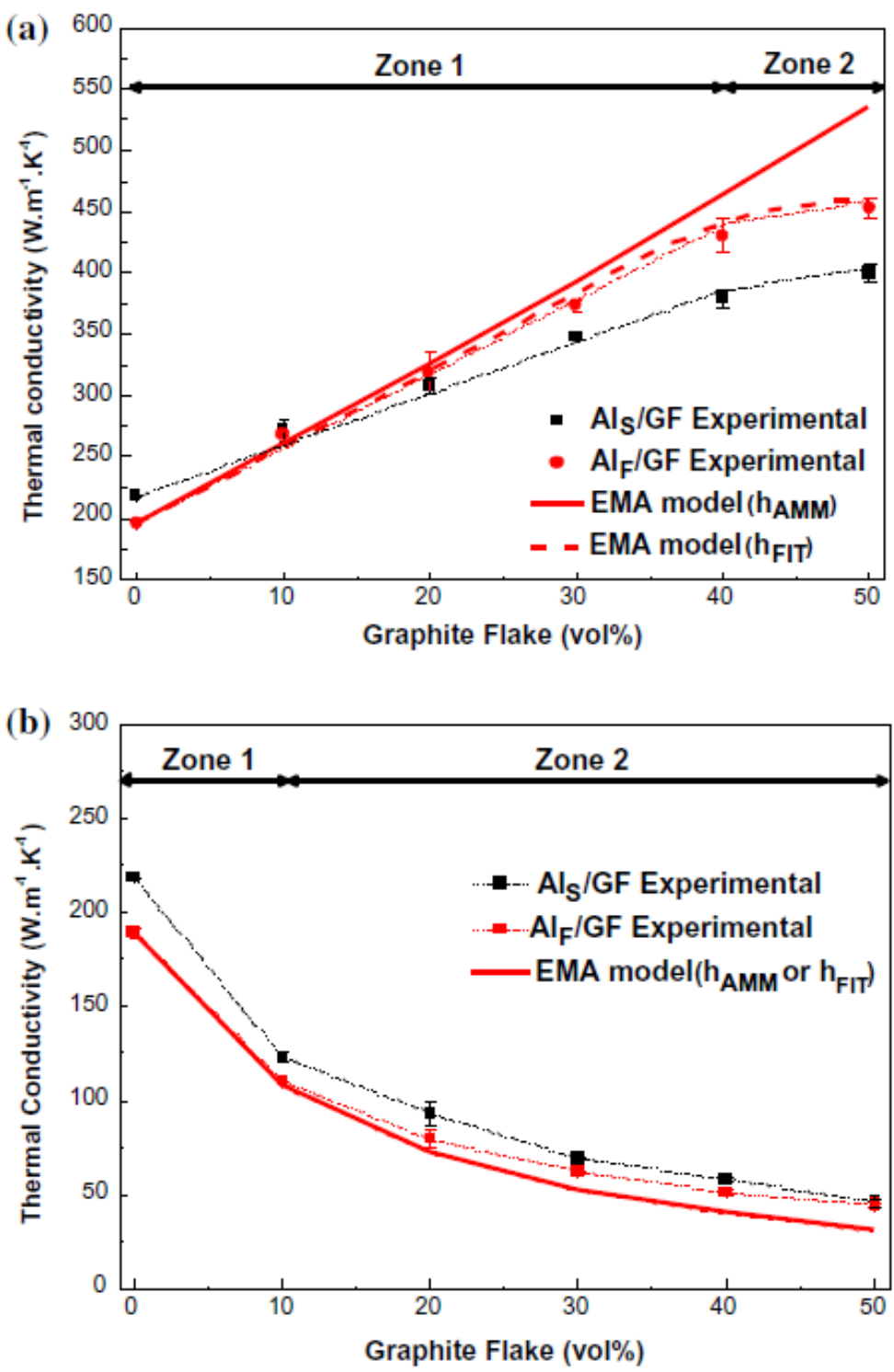

Figure 13 Comparison of experimental TC of $\mathrm{Al}_{\mathrm{S}} / \mathrm{GF}$ (black square) and $\mathrm{Al}_{\mathrm{F}} / \mathrm{GF}$ (red circle) composite materials with theoretical predictions by the EMA model (red solid line) in two directions: $\mathbf{a}$ in-plane TC (// to the GF) and $\mathbf{b}$ transverse TC $(\perp$ to the GF). 